\title{
AMENDMENTS ON SALINITY AND WATER RETENTION OF SAND BASE ROOTZONE AND TURFGRASS YIELD
}

\author{
Rahayu ${ }^{* 1}$, Yang Geun $\mathrm{Mo}^{2}$, and Choi Joon Soo ${ }^{2}$ \\ ${ }^{1}$ Department of Soil Science, Faculty of Agriculture, Sebelas Maret University, Surakarta \\ ${ }^{2}$ Department of Green Landscape Architecture Science, Bioresource Science, Dankook University, Korea \\ Submitted : 2019-02-20 Accepted : 2019-06-27
}

\begin{abstract}
This research was column pot experiment with turfgrass was Kentucky bluegrass (Poa pratensis) plant irrigated saline irrigation and the column soaked in saline water. Rootzone profile consisted of $20 \mathrm{~cm}$ using saline lake dredged up sand. The sand amendments of the root zone were soil, zeolite, bottom ash, and peat. The mixtures of topsoil were; $90 \%$ sand $+10 \%$ peat moss, $80 \%$ sand $+10 \%$ soil $+10 \%$ bottom ash, $80 \%$ sand $+20 \%$ soil, $90 \%$ sand $+5 \%$ peat $+5 \%$ zeolite, and $80 \%$ sand $+20 \%$ bottom ash . Interruption layer with coarse sand with diameters over $2 \mathrm{~mm}$ of $20 \mathrm{~cm}$ and $10 \mathrm{~cm}$ loamy soil as the bottom layer of the column. The result showed that Kentucky bluegrass could grow in sand based growing media amended by peat, sandy loam soils, bottom ash and zeolite being irrigated by $2 \mathrm{dS} \mathrm{m}^{-1}$ saline water. Sand-based growing media amended by peat resulted in the highest clipping weigh but showed the highest salt accumulations. Sand amended by bottom ash and applied gypsum decreased clipping weigh, decreased SAR and increased calcium ( $\mathrm{Ca}$ ) when compared to the soil + peat (SP). Sand amended by zeolite and gypsum decreased clipping weight, decreased sodium adsorption ratio (SAR) and higher $\mathrm{Ca}$. Higher soil moisture retention of growing media promoted the growth of Kentucky bluegrass in spring, and lower moisture content promoted the growth in summer and fall season.
\end{abstract}

Keywords: amendment, salinity, turfgrass, water content

How to Cite: Rahayu, Mo Y. G., and Soo C. J. (2019). Amendments on Salinity and Water Retention of Sand Base Rootzone and Turfgrass Yield. Sains Tanah Journal of Soil Science and Agroclimatology, 16(1): 103-111 (doi: 10.20961/stjssa.v16i1.28132)

Permalink/DOI: http://dx.doi.org/10.20961/stjssa.v16i1.28132

\section{INTRODUCTION}

Rapid urban population growth pressed land and fresh-water usage, thus golf course development was often pushed into non-fertile land with limited potable water. Attention and study on saline soil and saline water irrigation became necessary for turfgrass establishment. Many reports stated that turfgrass irrigation is typically considered as a low priority on

\footnotetext{
* Corresponding Author :

Email:rahayu_uns@yahoo.co.id
}

freshwater use (Kjelgren, Rupp, \& Kilgren, 2000; Marcum, 2006), and reused water is often the primary source of soluble salts (Silvertooth, 2001). Miyamoto, Chacon, Hossain, \& Martinez (2005) reported that water with the salinity of $1.3-1.5 \mathrm{dS} \mathrm{m}^{-1}$ can be used for irrigation. Also, saline water with $\mathrm{ECW}$ $0.7 \mathrm{dS} \mathrm{m}^{-1}$ could be used for irrigation on saline soil with ECe range from 1.3 to $1.5 \mathrm{dS} \mathrm{m}^{-1}$ (Mancino \& Pepper, 1992). However, using saline water caused many problems, such as soil salinization, salt injury to the turf and decreased salt leaching potential (Barrett- 
Lennard, 2003). Saline irrigation can cause the loss of plant stand, limited water uptake by the plant and specific ion toxicity and nutritional unbalance (Corwin \& Lesch, 2003). Irrigation using saline water was reported to cause the decline of turf quality (Qian, Wilhelm, \& Marcum, 2001). Salinity is an abiotic stress that affects the plant's ability to grow, develop, and achieve its full genetic potential (Läuchli \& Grattan, 2014). Salinity can reduce the turgor of epidermal cells in both mature and expanding tissue and in the short term, salinity reduces leaf elongation through osmotic effects on the turgor of expanding tissue of plant (Thiel, Lynch, \& Läuchli, 1988). Salinity decreases leaf water content, stomatal conductance, leaf water potential, and turgor potential. Under the saline condition, grass with higher water content is more tolerant than lower water content. Salinity reduced osmotic and water potential thus plants escape from dehydration and finally total dry matter production of a plant (Ahmad, Azooz, \& Prasad, 2013). Incorrect management in saline condition will result in salt accumulation in topsoil, causing the growth of the turfgrass to be unsustainable and the turf quality to be unacceptable. Commonly salt accumulation is affected by volume of water, water movement in infiltration, percolation and drainage, and evapotranspiration pattern (Silvertooth, 2001).

Zeolite has become a common soil ameliorate in sand based growing media. Zeolite is the hydrated aluminosilicate materials with high cation exchange capacity from 100-230 me $100 \mathrm{~g}^{-1}$ (Ok, Anderson, \& Ervin, 2003). Huang \& Petrovic (1994) reported that zeolite increased the water and nutrient holding a capacity of sand-based media used in golf course greens and sports fields. Zeolite was also applied to sand based growing media in saline condition. Soil also can be used as an amendment to sand base rootzone when the sand content should be ranged from 78 to $87 \%$ by weight for acceptable saturated hydraulic conductivity (McCoy, 2006). The other abundant and cheap amendment materials are bottom ash. Bottom ash (BA) is a waste of coal in power plant that represents $13-20 \%$ of the total ash remaining in the bottom of a coalfired boiler after combustion. The major constituent of $\mathrm{BA}$ are $\mathrm{Ca}, \mathrm{Al}, \mathrm{Fe}, \mathrm{Mg}, \mathrm{K}, \mathrm{Si}, \mathrm{Na}$ and $\mathrm{Ti}$, where $\mathrm{Ca}, \mathrm{Fe}, \mathrm{Mg}, \mathrm{K}$, and $\mathrm{Si}$ are essential to plant nutrients (Korcak, 1995). Gypsum $\left(\mathrm{CaSO}_{4}\right)$ has a role in improving flocculation, enhancing aggregate stability, increasing infiltration rate (Shainberg et al., 1989) and increasing $\mathrm{Ca}^{2+}$ content and replacing $\mathrm{Na}^{+}$. For sand based growing media, peat is the most frequently used organic amendments in golf course construction, because they have benefits in reducing the soil bulk density, improving rootzone aeration, increasing soil moisture retention, and gradual release of water available to plant (Bigelow, Bowman, Cassel, \& Rufty, 2001; Waltz, Quisenberry, \& McCarty, 2003). The growth of Kentucky bluegrass showed high clipping dry weight in June and low in August, while the weight of rhizome, root, and thatch increased with growth progressed in Korea (Yoon \& Lee, 1992). Increase of salinity caused root/shoot weight ratio to increase, where shoot growth decreased linearly in all levels of salinity and root growth was increased to a maximum point and then declined (Harivandi, Butler, \& Wu, 1992).

\section{MATERIALS AND METHODS}

This research was a column pot experiment conducted in Cheonan, Korea for 16 months, from June to October 2010. Turfgrass was Kentucky bluegrass (Poa pratensis) irrigated by fresh water during first one month after planting and then was followed by saline irrigation. Salinity levels of irrigation water were ECW of $2.0 \mathrm{dS} \mathrm{m}^{-1}$ Turfgrass be fertilized by complete fertilizer (11-5-7) and was applied 3 
times per year with rate $4 \mathrm{~g} \mathrm{~N} \mathrm{~m}^{-2}$ per each application. The column pot contained sandbased rootzone. Bottom of columns was soaked in pond saline water with $5-10 \mathrm{~cm}$ depth with $\mathrm{ECW}$ around 3-6 dS $\mathrm{m}^{-1}$. Rootzone profile consisted of $20 \mathrm{~cm}$ using sand from the bottom of the saline lake by dredged up way. The sand amendments of the rootzone were soil, zeolite, bottom ash, and peat. The amendments then are compared by application gypsum and no gypsum application. The mixtures of topsoil were; $90 \%$ sand $+10 \%$ peat moss, $80 \%$ sand $+10 \%$ soil +10 $\%$ bottom ash, $80 \%$ sand $+20 \%$ soil, $90 \%$ sand + $5 \%$ peat $+5 \%$ zeolite, and $80 \%$ sand $+20 \%$ bottom ash. Interruption layer with coarse sand with diameters over $2 \mathrm{~mm}$ of $20 \mathrm{~cm}$ and $10 \mathrm{~cm}$ loamy soil as the bottom layer of the column. The bottom layer of the column was saline soil with pH 6.7 and ECe $5.1 \mathrm{dS} \mathrm{m}^{-1}$, with sand, silt and clay contents of $63.8 \%, 32.0 \%$, and $4.9 \%$, respectively. The bottom of the column was plastic net thus the column was holly thus the pond water entry capillary to the rootzone.

The clipping tissue water content, soil moisture content, Magnesium and calcium, and SAR was investigated. Moisture contents were measured every 1 day, 2 days, and 3 days after irrigation with Time Domain Reflectometry (TDR). Calcium and magnesium analyze were by using 2 steps. The first step was to remove the $\mathrm{Ca}$ and $\mathrm{Mg}$ from the soil complex. Ten grams of dry soil was mixed with
$30 \mathrm{ml}$ of ammonium acetate $(1 \mathrm{M} \mathrm{pH} \mathrm{7)}$ in a flask and were shaken at $180 \mathrm{rpm}$ for 30 minutes, then were filtered and leached by 70 $\mathrm{ml}$ of ammonium acetate to get extract solution in the ratio 10:1 of ammonium acetate and soil. Total hardness $(\mathrm{Ca}+\mathrm{Mg})$ was analyzed by $10 \mathrm{ml}$ of extract solution buffered by $5 \mathrm{ml}$ ammoniac buffer ( $\mathrm{pH} 10)$. The color indicator was eriochrome black $\mathrm{T}$ solution and titration of the solution was by $0.01 \mathrm{M}$ EDTA. Calcium was analyzed by using $2 \mathrm{ml}$ solution extract buffered by $2 \mathrm{ml} \mathrm{NaOH}(2 \mathrm{M})$, colored by calcon indicator and then titrated by EDTA $0.01 \mathrm{M}$ solution. Subtracting the $\mathrm{Ca}$ in $\mathrm{ppm}$ from total hardness was the $\mathrm{Mg}$ in $\mathrm{ppm}$.

\section{RESULTS}

In Table 1 the moisture retention was increased significantly when soil and bottom ash were mixed together to sand that showed in SoBa and SSoBaGp. Soil material when applied together with gypsum in sand growing media increased the media moisture content, that showed at SSo compared to SSoGp in the first year of the experiment, moisture content of SPZ at 3 days after irrigation was higher than 2 days after irrigation, suggesting that there was a capillary rise of water movement. Table 1 showed also that soil moisture contents of SP and SSo were higher than other treatments when gypsum was not added.

Table 1. The soil moisture content of sand base growing media with various amendment materials in saline condition

\begin{tabular}{|c|c|c|c|c|c|c|c|c|c|c|c|c|c|c|c|}
\hline \multirow{4}{*}{ Top Soil } & \multicolumn{6}{|c|}{ The first year (day) } & \multicolumn{9}{|c|}{ The second year (day) } \\
\hline & \multicolumn{3}{|c|}{ Summer } & \multicolumn{3}{|c|}{ Fall } & \multicolumn{3}{|c|}{ Spring } & \multicolumn{3}{|c|}{ Summer } & \multicolumn{3}{|c|}{ Fall } \\
\hline & 1 & 2 & 3 & 1 & 2 & 3 & 1 & 2 & 3 & 1 & 2 & 3 & 1 & 2 & 3 \\
\hline & \multicolumn{15}{|c|}{ (\%) } \\
\hline $\mathrm{SP}^{2}$ & $8.6 \mathrm{bcd}$ & $6.4 \mathrm{a}-\mathrm{d}$ & $6.3 \mathrm{~cd}$ & $8.5 \mathrm{~b}$ & $7.1 \mathrm{bc}$ & $7.4 \mathrm{bc}$ & $14.8 \mathrm{a}$ & $11.9 \mathrm{a}$ & $9.3 a$ & $11.32 a$ & $10.83 a$ & $7.77 \mathrm{a}$ & $10.13 \mathrm{a}$ & $8.90 \mathrm{ab}$ & $8.77 a b^{x}$ \\
\hline SoBa & $13.8 \mathrm{ab}$ & $9.8 \mathrm{a}$ & $11.0 \mathrm{a}$ & $18.1 \mathrm{a}$ & $13.9 \mathrm{a}$ & $11.4 \mathrm{a}$ & $9.7 a b$ & $9.2 \mathrm{ab}$ & 7.5ab & 8.34ab & $5.93 \mathrm{a}$ & $6.77 \mathrm{a}$ & $8.33 a b$ & $7.85 \mathrm{abc}$ & 8.33abc \\
\hline SSo & $6.4 \mathrm{~d}$ & $4.6 \mathrm{~d}$ & $4.7 \mathrm{~d}$ & $6.8 \mathrm{~b}$ & $5.8 \mathrm{c}$ & $5.9 \mathrm{c}$ & $8.9 a b$ & $8.8 \mathrm{ab}$ & $6.6 a b$ & $8.07 a b$ & $5.47 \mathrm{a}$ & $7.97 \mathrm{a}$ & $10.58 \mathrm{a}$ & $10.43 \mathrm{a}$ & $10.00 \mathrm{a}$ \\
\hline SPZ & $12.8 \mathrm{abc}$ & $9.0 \mathrm{abc}$ & $10.3 a b$ & $11.0 \mathrm{~b}$ & $9.2 a b c$ & $10.1 \mathrm{ab}$ & $9.1 \mathrm{ab}$ & $8.5 \mathrm{ab}$ & $7.2 \mathrm{ab}$ & 7.37ab & $5.00 \mathrm{a}$ & $6.60 \mathrm{a}$ & $7.40 \mathrm{ab}$ & $6.90 \mathrm{bc}$ & 7.13abc \\
\hline $\mathrm{SBa}$ & $8.4 b c d$ & $6.4 a-d$ & $6.5 \mathrm{bcd}$ & $6.9 \mathrm{~b}$ & $6.7 b c$ & $6.7 \mathrm{bc}$ & $8.7 \mathrm{~b}$ & $8.1 \mathrm{ab}$ & $6.6 a b$ & $6.34 a b$ & $4.77 \mathrm{a}$ & $6.30 \mathrm{a}$ & $7.13 a b$ & $6.47 \mathrm{bc}$ & $6.78 \mathrm{bc}$ \\
\hline SPGp & $7.7 \mathrm{bcd}$ & $5.8 \mathrm{bcd}$ & $5.6 \mathrm{~d}$ & $7.4 \mathrm{~b}$ & $6.8 \mathrm{bc}$ & $7.0 \mathrm{bc}$ & $8.8 \mathrm{~b}$ & $8.2 \mathrm{ab}$ & $6.5 a b$ & $7.20 \mathrm{~b}$ & $5.23 \mathrm{a}$ & $6.77 \mathrm{a}$ & $9.05 a b$ & $8.65 a b c$ & $8.22 a b c$ \\
\hline SSoBaGp & $15.3 \mathrm{a}$ & $9.5 \mathrm{ab}$ & $11.9 \mathrm{a}$ & $13.5 a b$ & $11.6 a b$ & $11.5 a$ & $10.2 \mathrm{ab}$ & $10.0 \mathrm{ab}$ & $8.1 \mathrm{ab}$ & $8.18 a b$ & $6.57 \mathrm{a}$ & $8.30 \mathrm{a}$ & $8.30 a b$ & $8.07 a b c$ & $8.23 a b c$ \\
\hline SSoGp & $12.7 a-d$ & $9.5 \mathrm{ab}$ & $9.9 a b c$ & $9.4 \mathrm{~b}$ & $8.8 \mathrm{abc}$ & $9.0 b c$ & $11.4 \mathrm{ab}$ & $10.3 a b$ & $.4 a b$ & $9.70 a b$ & $6.77 a$ & $9.13 \mathrm{a}$ & $9.37 a b$ & $8.65 a b$ & $8.90 \mathrm{ab}$ \\
\hline SPZGp & $6.9 \mathrm{~cd}$ & $5.3 \mathrm{~cd}$ & $5.1 \mathrm{~d}$ & $6.8 \mathrm{~b}$ & $6.1 \mathrm{c}$ & $6.0 c$ & $7.6 \mathrm{~b}$ & $7.3 b$ & $5.9 \mathrm{~b}$ & $6.52 b$ & $4.10 \mathrm{a}$ & $5.80 \mathrm{a}$ & $6.22 \mathrm{~b}$ & $5.83 \mathrm{c}$ & $5.63 \mathrm{c}$ \\
\hline SBaGp & $8.9 \mathrm{bcd}$ & 6.0abcd & $6.1 \mathrm{~cd}$ & $10.1 \mathrm{~b}$ & $8.0 b c$ & $7.5 b c$ & $9.5 a b$ & $9.0 a b$ & $7.2 \mathrm{ab}$ & $7.27 a b$ & $4.97 \mathrm{a}$ & $6.47 \mathrm{a}$ & $7.82 \mathrm{ab}$ & $7.38 \mathrm{bc}$ & $6.93 \mathrm{bc}$ \\
\hline
\end{tabular}


With gypsum application, SSoBaGp and SSoGp have higher moisture content than the others. Moisture contents of 3 days after irrigation were $11.0,10.4$ and $11.9 \%$ in the first summer (first year), but they were decreased to 6.77, 6.60 and $8.30 \%$ in the second summer (second year).

Table 2 showed that the SSoGp growing media showed higher $\mathrm{pH}$ at the end of summer, fall, and also spring, where their $\mathrm{pH}$ values were close to 7.0. SP and SPGp showed a lower $\mathrm{pH}$ than the other growing media. Application of gypsum generally increased the $\mathrm{pH}$ of most growing media. Increased salinity from the fall season to spring was paralleled with the decrease of $\mathrm{pH}$. The SSoGp growing media showed higher $\mathrm{pH}$ at the end of summer, fall and also spring. Application of gypsum increased the $\mathrm{pH}$ of all treatments in the summer of the first year and the spring of the second year except the peat. Application of gypsum in peat amendment decreased the $\mathrm{pH}$ of media.

Table 3 showed that in the first year, the Ca content of the soil was increased in growing media when gypsum was applied. In the falls of the first year and second year, SPZ and SPZGp showed $\mathrm{Ca}$ contents higher than the other treatments. In the spring of the second year, SSo and SSoGp showed higher Ca content than

Table 2. The $\mathrm{pH}$ of sand base growing media with various amendment materials in saline condition.

\begin{tabular}{|c|c|c|c|c|c|}
\hline \multirow{2}{*}{ Topsoil } & \multicolumn{2}{|l|}{ First year } & \multicolumn{3}{|c|}{ Second year } \\
\hline & Summer & Fall & Spring & Summer & Fall \\
\hline SPx & $6.27 f$ & $6.76 \mathrm{~cd}$ & $6.68 \mathrm{~b}$ & $6.0 \mathrm{f}$ & $6.2 f^{*}$ \\
\hline SSoBa & $6.24 \mathrm{f}$ & $6.78 \mathrm{~cd}$ & $6.50 \mathrm{e}$ & $6.5 \mathrm{e}$ & $6.2 \mathrm{f}$ \\
\hline SSo & $6.42 \mathrm{ef}$ & $7.08 \mathrm{a}$ & $6.48 \mathrm{e}$ & $6.9 \mathrm{a}$ & $6.4 \mathrm{e}$ \\
\hline SPZ & $6.56 \mathrm{de}$ & $6.95 \mathrm{~b}$ & $6.53 \mathrm{de}$ & $6.7 \mathrm{~cd}$ & $6.5 \mathrm{~d}$ \\
\hline $\mathrm{SBa}$ & $6.63 \mathrm{cde}$ & $6.74 \mathrm{~d}$ & $6.54 \mathrm{~d} \mathrm{e}$ & $6.6 \mathrm{~d}$ & $6.7 \mathrm{bc}$ \\
\hline SPGp & $6.51 \mathrm{de}$ & $6.62 \mathrm{e}$ & $6.58 \mathrm{~cd}$ & $6.1 \mathrm{f}$ & $6.7 \mathrm{bc}$ \\
\hline SSo BaGp & $6.70 \mathrm{bcd}$ & $6.85 c$ & $6.65 \mathrm{bc}$ & $6.6 \mathrm{~d}$ & $7.0 \mathrm{a}$ \\
\hline SSoGp & $7.03 \mathrm{a}$ & $7.05 \mathrm{a}$ & $6.78 \mathrm{a}$ & $6.8 \mathrm{ab}$ & $6.8 \mathrm{~b}$ \\
\hline SPZGp & $6.86 \mathrm{ab}$ & $7.00 \mathrm{ab}$ & $6.83 a$ & $6.6 \mathrm{~d}$ & $6.6 \mathrm{c}$ \\
\hline SBaGp & $6.79 \mathrm{bc}$ & $7.07 \mathrm{a}$ & $6.84 \mathrm{a}$ & $6.8 \mathrm{bc}$ & $6.6 \mathrm{c}$ \\
\hline
\end{tabular}

the other treatments. After one season from the establishment, soil and zeolite showed a higher Ca content than the other treatments. During the excessive rain period of the summer of the second year, the soil and zeolite showed a higher Ca level than the other treatments. Fine material in bottom ash also cannot hold $\mathrm{Ca}$ in saline water irrigation condition, thus $\mathrm{Ca}$ contents in SBa and SBaGp were lower than any other treatments at the fall of the second year. Ca content in SSoGp was lower than SSo, suggesting that gypsum in soil may have increased leaching of $\mathrm{Ca}$.

Table 4 showed that irrigation water with a high concentration of $\mathrm{Na}$ and $\mathrm{Mg}$ may have caused the accumulation of $\mathrm{Mg}$.

Table 3. The calcium content of sand base growing media with various amendment materials in saline condition.

\begin{tabular}{lcllll}
\hline & \multicolumn{3}{c}{ Year first year } & \multicolumn{3}{c}{ Year second year } \\
\cline { 2 - 6 } Topsoil & Summer & \multicolumn{1}{c}{ Fall } & \multicolumn{1}{c}{ Spring } & Summer & Fall \\
\cline { 2 - 6 } & \multicolumn{5}{c}{ (ppm) } \\
\hline SPz & $80.8 \mathrm{~d}$ & $106.9 \mathrm{c}$ & $122.2 \mathrm{~cd}$ & $83.5 \mathrm{~d}$ & $169.7 \mathrm{aby}$ \\
SSoBa & $102.9 \mathrm{~cd}$ & $113.6 \mathrm{bc}$ & $141.6 \mathrm{bcd}$ & $110.2 \mathrm{bc}$ & $161.0 \mathrm{ab}$ \\
SSo & $108.2 \mathrm{~cd}$ & $114.2 \mathrm{bc}$ & $157.0 \mathrm{ab}$ & $140.3 \mathrm{a}$ & $173.7 \mathrm{ab}$ \\
SPZ & $105.5 \mathrm{~cd}$ & $142.3 \mathrm{ab}$ & $130.3 \mathrm{bcd}$ & $117.6 \mathrm{abc}$ & $187.0 \mathrm{a}$ \\
SBa & $82.2 \mathrm{~d}$ & $110.2 \mathrm{c}$ & $110.2 \mathrm{~d}$ & $92.9 \mathrm{ab}$ & $151.0 \mathrm{~b}$ \\
\hline SPGp & $165.7 \mathrm{ab}$ & $110.9 \mathrm{c}$ & $110.9 \mathrm{~d}$ & $98.2 \mathrm{~cd}$ & $159.0 \mathrm{ab}$ \\
SSo BaGp & $175.7 \mathrm{ab}$ & $122.9 \mathrm{bc}$ & $141.6 \mathrm{bcd}$ & $126.9 \mathrm{ab}$ & $167.0 \mathrm{ab}$ \\
SSoGp & $192.4 \mathrm{a}$ & $123.6 \mathrm{bc}$ & $185.0 \mathrm{a}$ & $126.9 \mathrm{ab}$ & $167.0 \mathrm{ab}$ \\
SPZGp & $181.0 \mathrm{ab}$ & $165.7 \mathrm{a}$ & $148.3 \mathrm{bc}$ & $134.9 \mathrm{ab}$ & $184.4 \mathrm{a}$ \\
SBaGp & $140.9 \mathrm{bc}$ & $125.6 \mathrm{bc}$ & $127.6 \mathrm{bcd}$ & $127.6 \mathrm{ab}$ & $149.6 \mathrm{~b}$ \\
\hline y Means within a column followed by the same letter are not significantly \\
different based on LSD. \\
z S= sand; P=peat; Ba= bottom ash; So= soil; Z= zeolite; Gp=gypsum.
\end{tabular}

Table 4. The magnesium content of sand base growing media with various amendment materials in saline condition.

\begin{tabular}{llllll}
\hline \multirow{2}{*}{ Topsoil } & \multicolumn{4}{l}{ Year first year } & \multicolumn{3}{l}{ Year second year } \\
\cline { 2 - 6 } & Summer & Fall & Spring & Summer & Fall \\
\hline SPz & $143.4 \mathrm{a}$ & $26.3 \mathrm{a}$ & $147.7 \mathrm{a}$ & $64.8 \mathrm{de}$ & $198.9 \mathrm{bcy}$ \\
SSoBa & $174.6 \mathrm{a}$ & $10.1 \mathrm{ab}$ & $164.8 \mathrm{a}$ & $89.1 \mathrm{abcd}$ & $234.6 \mathrm{ab}$ \\
SSo & $112.6 \mathrm{a}$ & $17.8 \mathrm{ab}$ & $135.7 \mathrm{a}$ & $97.2 \mathrm{ab}$ & $247.2 \mathrm{ab}$ \\
SPZ & $175.0 \mathrm{a}$ & $10.9 \mathrm{ab}$ & $150.4 \mathrm{a}$ & $78.6 \mathrm{bcde}$ & $202.6 \mathrm{abc}$ \\
SBa & $185.2 \mathrm{a}$ & $4.1 \mathrm{~b}$ & $159.5 \mathrm{a}$ & $59.2 \mathrm{e}$ & $194.1 \mathrm{bc}$ \\
\hline SPGp & $140.6 \mathrm{a}$ & $7.7 \mathrm{~b}$ & $165.2 \mathrm{a}$ & $68.1 \mathrm{cde}$ & $245.5 \mathrm{ab}$ \\
SSo BaGp & $144.6 \mathrm{a}$ & $14.6 \mathrm{ab}$ & $155.7 \mathrm{a}$ & $103.3 \mathrm{a}$ & $237.0 \mathrm{ab}$ \\
SSoGp & $136.5 \mathrm{a}$ & $14.2 \mathrm{ab}$ & $138.5 \mathrm{a}$ & $91.2 \mathrm{abc}$ & $156.0 \mathrm{c}$ \\
SPZGp & $173.8 \mathrm{a}$ & $8.9 \mathrm{~b}$ & $148.6 \mathrm{a}$ & $78.2 \mathrm{bcde}$ & $250.8 \mathrm{ab}$ \\
SBaGp & $159.6 \mathrm{a}$ & $15.0 \mathrm{ab}$ & $133.8 \mathrm{a}$ & $72.5 \mathrm{cde}$ & $269.8 \mathrm{a}$ \\
\hline y Means within a column followed by the same letter are not significantly \\
different based on LSD. \\
z S= sand; P=peat; Ba= bottom ash; So= soil; Z= zeolite; Gp=gypsum.
\end{tabular}


Decrease of $\mathrm{Mg}$ more than Ca in the fall of the first year and the summer of the second year may due to the different characteristic of both cation. At the summer of the first year, the application of gypsum did not increase the content of $\mathrm{Mg}$ in growing media. Summer of the second year was the period when most leaching occurred by frequent rain. In peat + zeolite modified soil, the $\mathrm{Mg}$ content was relatively consistent in the soil with little effect of gypsum addition. Figure 1 showed that SAR was increased from the summer to the fall of the first year, and decreased from the spring to the summer of the second year. In the first year of the experiment, SAR was generally higher in the fall season of dry weather. However, SAR was significantly decreased by high rainfall during summer. Addition of gypsum generally lowered SAR in most treatments.

Table 5 showed that total clipping fresh weight of SSoGp was higher than SP and SPGp, whereas the other treatments showed lower clipping yield than SP. In dry condition, the SP, SSo, SPGp, and SSoGp resulted in higher clipping fresh weight than the other treatments, while in wet condition SP, SPZ and SPGp resulted in higher clipping fresh weight. The SP, SSo, SPGp, and SSoGp resulted in higher clipping fresh weight than other treatments during fall and spring season. In the dry period, soil and peat addition resulted in higher clipping yield. Application of gypsum increased the clipping fresh weight of SSo and decreased the clipping dry weight of SPZGp. Application of gypsum increased the average clipping fresh weight of treatments such as SSo, SBa, and SsoBa.

Table 6 showed that the average of the tissue water content of Kentucky bluegrass was higher in SP than the other treatments. The tissue water content of Kentucky bluegrass fluctuated in all of the treatment with range 160 to $250 \%$. At fall season, SPZGp and SPZ have significantly lower tissue water content than the control, while SSoBa, SSo, and SSoGp showed higher tissue water content. This result suggests that soil can improve tissue water content, while zeolite declined tissue water content of Kentucky bluegrass. However, at spring season SPGp showed higher tissue water content, while SSoBa and SPZ showed lower tissue water content. Application of gypsum was no effect in tissue water content of Kentucky bluegrass. The maximum tissue water content was shown at the end of spring compare the other time of observation.

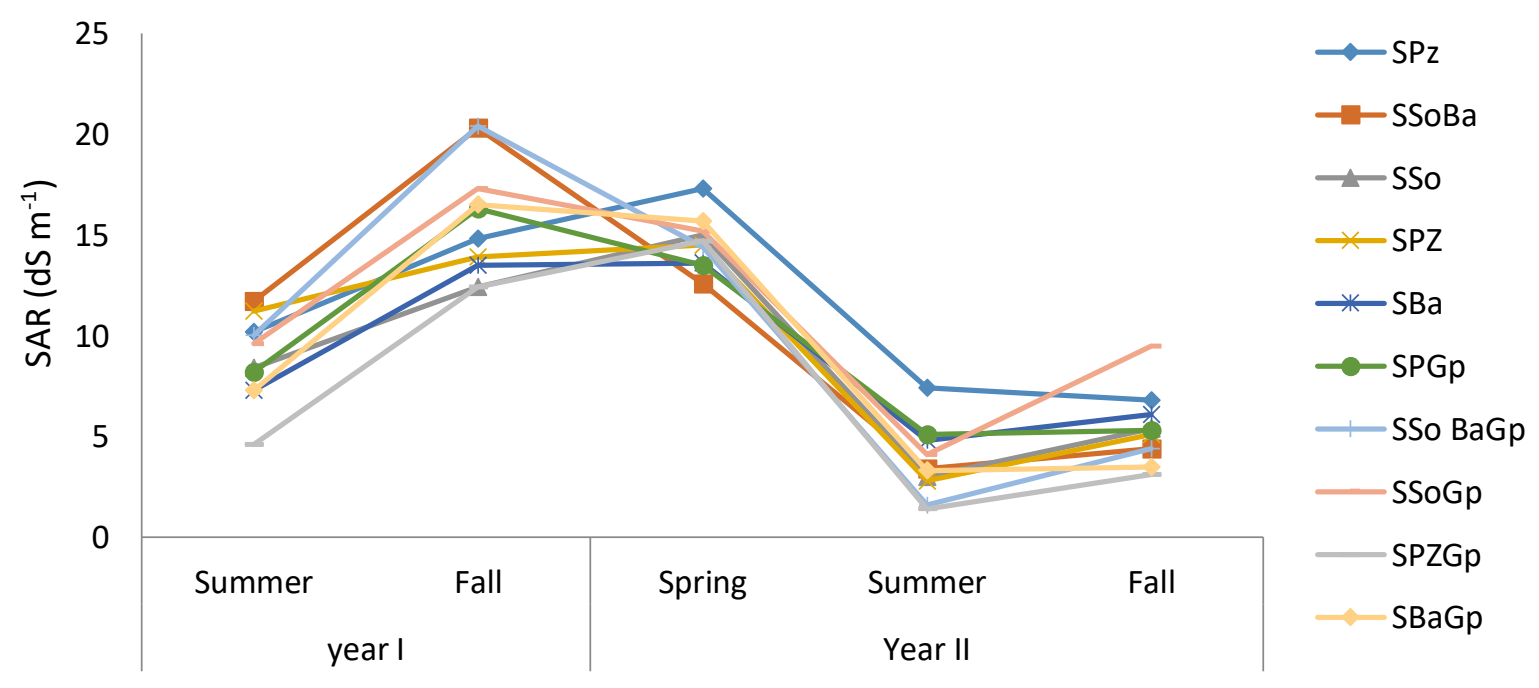

Figure 1. Sodium Adsorption ratio of soil.

${ }^{z} \mathrm{~S}=$ sand; $\mathrm{P}=$ peat; $\mathrm{Ba}=$ bottom ash; So= soil; $\mathrm{Z}=$ zeolite; $\mathrm{Gp}=$ gypsum. 
Table 5. Clipping fresh weight of Kentucky bluegrass at various soil amendments growing media in saline condition.

\begin{tabular}{|c|c|c|c|c|c|c|c|c|c|c|c|c|c|}
\hline \multirow[t]{2}{*}{ Topsoil } & \multicolumn{2}{|l|}{ Sept } & \multicolumn{2}{|l|}{ Oct } & \multirow{2}{*}{$\begin{array}{l}\text { Nop } \\
1\end{array}$} & \multirow{2}{*}{$\begin{array}{l}\text { May } \\
4\end{array}$} & \multicolumn{3}{|c|}{ June } & \multicolumn{2}{|l|}{ July } & \multicolumn{2}{|l|}{$\begin{array}{c}\text { Augus } \\
t\end{array}$} \\
\hline & 1 & 15 & 1 & 15 & & & 19 & 1 & 15 & 30 & 20 & 4 & 20 \\
\hline SP & $57.4 \mathrm{a}$ & $24.3 \mathrm{a}$ & $24.3 \mathrm{ab}$ & $24.5 \mathrm{a}$ & $4.7 \mathrm{a}$ & $19.3 \mathrm{ab}$ & $38.0 \mathrm{a}$ & $55.8 \mathrm{a}$ & $27.1 \mathrm{abc}$ & $18.3 \mathrm{~b}$ & $60.5 \mathrm{ab}$ & $68.6 \mathrm{a}$ & $45.95 a$ \\
\hline SSoBa & $56.5 \mathrm{a}$ & $22.6 \mathrm{a}$ & $17.2 \mathrm{bc}$ & $21.5 \mathrm{a}$ & $4.9 \mathrm{a}$ & $13.9 \mathrm{~b}$ & $30.9 \mathrm{a}$ & $43.7 \mathrm{abc}$ & $24.8 \mathrm{abc}$ & 17.7 b & $61.4 \mathrm{ab}$ & $53.8 \mathrm{bc}$ & $37.79 a$ \\
\hline SSo & $41.8 \mathrm{ab}$ & $21.7 \mathrm{a}$ & $23.5 \mathrm{abc}$ & $25.4 \mathrm{a}$ & $4.8 \mathrm{a}$ & $25.3 \mathrm{a}$ & $35.3 \mathrm{a}$ & $45.9 \mathrm{abc}$ & $25.8 \mathrm{abc}$ & $21.3 \mathrm{ab}$ & $60.6 \mathrm{ab}$ & $62.5 \mathrm{ab}$ & $40.91 a$ \\
\hline SPZ & $54.8 \mathrm{a}$ & $25.2 \mathrm{a}$ & 17.7 bc & $22.6 \mathrm{a}$ & $3.1 \mathrm{a}$ & $14.4 \mathrm{~b}$ & $29.7 a$ & $35.9 c$ & $23.4 \mathrm{c}$ & $21.5 \mathrm{ab}$ & $62.8 \mathrm{ab}$ & $57.4 \mathrm{bc}$ & $43.64 a$ \\
\hline $\mathrm{SBa}$ & $51.1 \mathrm{ab}$ & $21.7 \mathrm{a}$ & $23.5 \mathrm{abc}$ & $22.3 \mathrm{a}$ & $3.4 \mathrm{a}$ & $14.6 \mathrm{~b}$ & $30.0 \mathrm{a}$ & $37.3 \mathrm{bc}$ & $23.2 \mathrm{c}$ & $17.7 \mathrm{~b}$ & $56.4 \mathrm{ab}$ & $46.5 \mathrm{c}$ & $40.72 a$ \\
\hline SPGp & 58.3 a & $27.3 a$ & $27.4 \mathrm{a}$ & $24.9 \mathrm{a}$ & $3.4 \mathrm{a}$ & $24.6 \mathrm{a}$ & $38.9 \mathrm{a}$ & $52.9 \mathrm{ab}$ & $30.3 \mathrm{a}$ & $17.2 \mathrm{~b}$ & $61.6 \mathrm{ab}$ & $62.2 \mathrm{ab}$ & $39.07 a$ \\
\hline SSoBaGp & $50.0 \mathrm{ab}$ & $25.5 \mathrm{a}$ & $18.5 \mathrm{bc}$ & $18.8 \mathrm{a}$ & $3.8 \mathrm{a}$ & $15.2 \mathrm{~b}$ & $36.2 \mathrm{a}$ & $44.7 \mathrm{abc}$ & $23.6 \mathrm{bc}$ & $18.4 \mathrm{~b}$ & $53.5 \mathrm{~b}$ & $51.3 \mathrm{bc}$ & $38.55 a$ \\
\hline SSoGp & $57.8 \mathrm{a}$ & $26.0 \mathrm{a}$ & $20.4 a b c$ & $27.9 \mathrm{a}$ & $4.9 \mathrm{a}$ & $17.2 \mathrm{~b}$ & $33.4 \mathrm{a}$ & $53.3 \mathrm{a}$ & $29.1 \mathrm{ab}$ & $28.6 \mathrm{a}$ & $66.2 \mathrm{a}$ & $60.6 a b$ & $35.90 a$ \\
\hline SPZGp & $35.9 \mathrm{~b}$ & $19.6 \mathrm{a}$ & $15.8 \mathrm{c}$ & $20.2 \mathrm{a}$ & $3.6 \mathrm{a}$ & $18.7 \mathrm{ab}$ & $32.4 \mathrm{a}$ & $45.3 a b c$ & 25.1abc & $15.8 \mathrm{~b}$ & $60.3 \mathrm{ab}$ & 53.5 bc & $35.20 \mathrm{a}$ \\
\hline SBaGp & $51.5 a^{*} *$ & $23.2 \mathrm{a}$ & $20.0 \mathrm{abc}$ & $24.4 \mathrm{a}$ & $5.0 \mathrm{a}$ & $18.7 \mathrm{ab}$ & $37.6 \mathrm{a}$ & $51.5 \mathrm{abc}$ & $22.7 \mathrm{c}$ & $19.7 \mathrm{ab}$ & $59.0 \mathrm{ab}$ & $55.0 \mathrm{bc}$ & $40.10 a$ \\
\hline
\end{tabular}

Table 6. The leaf water content of Kentucky bluegrass at various soil amendments growing media in saline condition.

\begin{tabular}{|c|c|c|c|c|c|c|c|c|c|c|c|c|c|}
\hline \multirow{2}{*}{ Topsoil } & \multicolumn{2}{|l|}{ Sept } & \multicolumn{3}{|l|}{ Oct } & \multicolumn{2}{|l|}{ May } & \multicolumn{2}{|l|}{ June } & \multicolumn{2}{|l|}{ July } & \multicolumn{2}{|l|}{ Aug } \\
\hline & 1 & 15 & 1 & 15 & 30 & 4 & 19 & 1 & 15 & 30 & 20 & 4 & 19 \\
\hline SP & $250.6 a b$ & $207.3 \mathrm{a}$ & $201.4 \mathrm{a}$ & $211.6 \mathrm{a}$ & $184.5 a b$ & $201.4 a$ & $236.8 a$ & $217.9 b$ & $193.5 \mathrm{a}$ & 203.6ab & 201.0a & $210.1 \mathrm{a}$ & $287.2 \mathrm{a}$ \\
\hline SSoBa & 279.8 a & $211.0 \mathrm{a}$ & $198.0 \mathrm{a}$ & $207.8 \mathrm{a}$ & 176.9ab & $170.3 a$ & $227.8 a$ & $219.7 b$ & $178.3 \mathrm{~d}$ & 199.9ab & 197.7ab & $201.4 a b$ & $242.6 a$ \\
\hline SSo & $257.6 a b$ & $192.6 \mathrm{a}$ & $198.5 \mathrm{a}$ & $212.3 \mathrm{a}$ & 177.6ab & $199.6 a$ & $232.8 a$ & $219.4 b$ & $181.5 \mathrm{bcd}$ & $202.4 \mathrm{ab}$ & 196.3ab & 201.1ab & $250.9 a$ \\
\hline SPZ & 232.9ab & $211.2 \mathrm{a}$ & $201.3 \mathrm{a}$ & $206.4 \mathrm{a}$ & $161.8 \mathrm{~b}$ & 187.3a & $233.0 \mathrm{a}$ & $220.0 \mathrm{~b}$ & $190.5 \mathrm{abc}$ & $205.8 \mathrm{ab}$ & 199.1ab & $203.4 a b$ & $254.9 a$ \\
\hline SBa & $250.4 \mathrm{ab}$ & $191.7 \mathrm{a}$ & $204.6 \mathrm{a}$ & $205.0 \mathrm{a}$ & $172.1 \mathrm{ab}$ & $164.4 a$ & $223.1 a$ & $219.6 b$ & $179.7 \mathrm{~cd}$ & $198.5 \mathrm{ab}$ & 195.4ab & $189.0 \mathrm{~b}$ & $213.8 \mathrm{a}$ \\
\hline SPGp & $252.8 \mathrm{ab}$ & $205.6 a$ & $201.2 \mathrm{a}$ & $208.9 a$ & 170.3ab & 191.7a & $236.0 a$ & $234.2 a$ & 191.8ab & 234.9 a & $201.0 \mathrm{a}$ & 202.7ab & $201.4 a$ \\
\hline SSoBaGp & $254.5 \mathrm{ab}$ & $213.5 \mathrm{a}$ & $188.4 \mathrm{a}$ & $201.8 \mathrm{a}$ & $165.0 \mathrm{~b}$ & $190.2 a$ & $228.7 a$ & $217.0 \mathrm{~b}$ & $182.0 \mathrm{a}-\mathrm{d}$ & $197.8 \mathrm{ab}$ & $200.4 \mathrm{a}$ & 196.6ab & $228.9 a$ \\
\hline SSoGp & $259.2 a b$ & $213.1 \mathrm{a}$ & $192.7 \mathrm{a}$ & $209.9 a$ & 168.9ab & $163.8 \mathrm{a}$ & $227.4 a$ & $216.1 b$ & $193.5 \mathrm{a}$ & $211.9 a b$ & $205.8 a$ & $203.2 \mathrm{ab}$ & $237.9 a$ \\
\hline SPZGp & $214.1 \mathrm{~b}$ & $189.1 \mathrm{a}$ & $190.6 \mathrm{a}$ & $199.1 \mathrm{a}$ & 171.9ab & 201.1a & $228.9 a$ & $218.7 b$ & $185.9 \mathrm{bcd}$ & 170.7 b & 197.9ab & 196.0ab & $205.6 a$ \\
\hline SBaGpx & $244.0 \mathrm{ab}$ & $188.4 \mathrm{a}$ & $189.6 \mathrm{a}$ & $203.7 \mathrm{a}$ & $192.0 \mathrm{a}$ & $190.8 a$ & $240.8 a$ & $219.8 b$ & $181.0 \mathrm{bcd}$ & $204.6 \mathrm{ab}$ & $184.9 \mathrm{~b}$ & $192.2 a b$ & $225.0 \mathrm{a}$ \\
\hline
\end{tabular}

\section{DISCUSSION}

Refer to Table 1 the amendment of soil mixed with bottom ash and soil mixed to gypsum increased sand based medium moisture retention. This result correlates with Buck, CPSSc, \& Labuz (2005) that soil and bottom ash has high silt content that can increase soil moisture storage. Also, increased salt accumulation can cause an increase in water content (Thompson, Gallardo, Fernández, Valdez, \& Martínez-Gaitán, 2007). Table 1 also showed that zeolite amendment increased the soil moisture content of growing media, however soil moisture content was decreased when zeolite was applied together with gypsum. Al-Busaidi et al. (2008) reported that application of zeolite enhanced water content and water residence under saline treatment and salt holding capacity of the soil. The ability of zeolite in enhancing capillary rise movement was reported by Huang \& Petrovic (1994); Wasura \& Petrovic (2001), where it was deducted that zeolite can improve capillary water movement. In Table 1 SSoBaGp and SSoGp have higher moisture content than the other treatment. Buck et al. (2005) reported that bottom ash improves the permeability of soils. Improved permeability of soil can reduce the water content of the topsoil. Application of gypsum may increase the rate of infiltration and may increase field-saturated hydraulic conductivities (Ilyas, Miller, \& Qureshi, 1993). Haisheng et al. (2008) reported that gypsum can increase $\mathrm{Ca}^{2+}$ content and replace $\mathrm{Na}^{+}$and $\mathrm{Mg}^{2+}$ to improve soil permeability.

Increased salinity from the fall season to spring was paralleled with the decrease of $\mathrm{pH}$. Wilhelm, Alshammary, \& Qian (2010) reported that soil $\mathrm{pH}$ was low with increased salinity by saline water irrigation. Application of gypsum 
in peat amendment decreased the $\mathrm{pH}$ of media. Applied gypsum increases conditions such as infiltration rate (Shainberg et al., 1989), soil permeability (Haisheng et al., 2008) and supply of soluble calcium (Mzezewa, Gotosa, \& Nyamwanza, 2003). This enhanced condition by applied gypsum may have increased the decomposition of peat, resulting in the release of organic acid into the soil solution, thus decreasing the $\mathrm{pH}$ of the growing media (Table 1). Supply of Ca from gypsum addition may have also acted in buffering the $\mathrm{pH}$ of bottom ash from acidification by rainfall. Korean bottom ash used in this research was reported to contain high Ca level-up to 61\% (Lim, Han, Ahn, \& You, 2010). Johnson \& Furrer (2002) also reported that bottom ash contains soluble salt such as calcite, which plays a predominant buffering constituent in time as soluble basic Ca salts.

Base on Table 3, during the excessive rain period, the soil and zeolite amendments showed a higher $\mathrm{Ca}$ level in the sand media. This result correlates with Al-Busaidi et al. (2008) that states the zeolite restrict nutrient and salt leaching. Bottom ash and peat resulted in lower Ca content from the summer of the first year to the summer of the second year. Even though the bottom ash amendment contains $\mathrm{Ca}, \mathrm{Mg}$ and $\mathrm{Na}$ (Korcak, 1995), those elements are still in the primer mineral, thus bottom ash cannot work as an immediate source. Table 3 showed that Ca content in SSoGp was lower than SSo, suggesting that gypsum in soil may have increased leaching of Ca. Application of gypsum to soil increased the solubilities of $\mathrm{Ca}$ and $\mathrm{Mg}$ and decreased the solubility of $\mathrm{Na}$. Since binding affinity is $\mathrm{Na}^{+}<$ $\mathrm{Mg}^{2+}<\mathrm{Ca}^{2+}$ with clay (Rytwo, Banin, \& Nir, 1996), if the Ca was retained more by the clay, then the calcium content of the soil would have been higher. Haisheng et al. (2008) reported that gypsum as chemical modifying agents is the main component of saline-sodic soil amelioration, which can increase $\mathrm{Ca}^{2+}$ content and replace $\mathrm{Na}^{+}$and $\mathrm{Mg}^{2+}$ from soil colloids to improve soil condition and soil permeability. Supply of Ca from gypsum may be the main reason for lowering SAR. However, amendments of peat + zeolite + gypsum showed lower SAR than the other treatment in the fall season of the second year, was showed in Figure 1. At the summer of the second year when the salt was leached out from root zone, soil+ bottom ash + gypsum and peat +zeolite + gypsum showed lower SAR than the others, and significantly lower than the peat amendments. The high clipping fresh weight yield of SPZ and SPZGp in Table 5 showed that the ability of zeolite to improve turfgrass growth in a wet season. The effect of zeolite to improve the turfgrass growth may be related to CEC, nutrient retention and infiltration. Huang \& Petrovic (1994) reported that zeolite increase nutrient holding capacity, CEC, and reduced nutrient leaching potential of sand based media (Wasura \& Petrovic, 2001).

\section{CONCLUSION}

Soil, peat, and bottom ash showed beneficiary as amendment of sand based growing media in saline condition even though soil and bottom ash amendment showed lower clipping fresh wight. Peat as amendment resulted in high clipping weigh of turfgrass even though showed salt accumulations. Gypsum can increase Ca content and reduce SAR when added to bottom ash or zeolite amendment. Higher soil moisture retention of growing media promoted the growth of Kentucky bluegrass in spring, and lower moisture content promoted the growth in summer and fall season.

\section{REFERENCES}

Ahmad, P., Azooz, M. M., \& Prasad, M. N. V. (2013). Ecophysiology and Responses of Plants under Salt Stress (P. Ahmad, M. M. Azooz, \& M. N. V. Prasad, Eds.). New York: 
Springer 10.1007/978-1-4614-4747-4

Al-Busaidi, A., Yamamoto, T., Inoue, M., Eneji, A. E., Mori, Y., \& Irshad, M. (2008). Effects of Zeolite on Soil Nutrients and Growth of Barley Following Irrigation with Saline Water. Journal of Plant Nutrition, 31(7), 1159-1173.

10.1080/01904160802134434

Barrett-Lennard, E. G. (2003). The interaction between waterlogging and salinity in higher plants: causes, consequences and implications. Plant and Soil, 253(1), 3554. 10.1023/A:1024574622669

Bigelow, C. A., Bowman, D. C., Cassel, D. K., \& Rufty, T. W. (2001). Creeping Bentgrass Response to Inorganic Soil Amendments and Mechanically Induced Subsurface Drainage and Aeration. Crop Science, 41(3), 797-805.

Buck, J. K., CPSSc, \& Labuz, L. L. (2005). Bottom Ash Fines as a Soil Amendment for Turfgrass and Site Closure-Laboratory and Mesocosm Studies at PPL Brunner Island and Montour Steam Electric Station. Retrieved from http://www.flyash.info

Corwin, D. L., \& Lesch, S. M. (2003). Application of Soil Electrical Conductivity to Precision Agriculture. Agronomy Journal, 95(3), 455-471. 10.2134/agronj2003.0455

Haisheng, H., Wenjie, W., Hong, Z., Yuangang, Z., Zhonghua, Z., Yu, G., ... Xingyang, Y. (2008). Influences of addition of different krilium in saline-sodic soil on the seed germination and growth of cabbage. Acta Ecologica Sinica, 28(11), 5338-5346. 10.1016/S1872-2032(09)60009-3

Harivandi, M. A., Butler, J. D., \& Wu, L. (1992). Salinity and Turfgrass Culture. In Turfgrass- Agronomy Monograph USA: American Society of Agronomy, Crop Science Society of America, Soil Science Society of America (pp. 207-229). 10.2134/agronmonogr32.c6

Huang, Z. T., \& Petrovic, A. M. (1994). Physical Properties of Sand as Affected by Clinoptilolite Zeolite Particle Size and Quantity. Journal of Turfgrass Management, 1(1), 1-15. 10.1300/J099v01n01_01

Ilyas, M., Miller, R. W., \& Qureshi, R. H. (1993). Hydraulic Conductivity of Saline-Sodic Soil after Gypsum Application and Cropping. Soil Science Society of America Journal, 57(6), 1580-1585. $10.2136 /$ sssaj1993.03615995005700060 $031 x$

Johnson, C. A., \& Furrer, G. (2002). Influence of Biodegradation Processes on The Duration of $\mathrm{CaCO} 3$ as a $\mathrm{pH}$ Buffer in Municipal Solid Waste Incinerator Bottom Ash. Environmental Science \& Technology, 36(2), 215-220.

Kjelgren, R., Rupp, L., \& Kilgren, D. (2000). Water Conservation in Urban Landscapes. Hort. Science, 35(6), 1037-1040.

Korcak, R. F. (1995). Utilization of Coal Combustion by-Products in Agriculture and Horticulture. In D. L. Karlen, R. J. Wright, \& W. O. Kemper (Eds.), Agricultural Utilization of Urban and Industrial By-Products. USA: American Society of Agronomy, Crop Science Society of America, Soil Science Society of America (pp. 107-130).

Läuchli, A., \& Grattan, S. R. (2014). Plant Abiotic Stress: Salt. In Encyclopedia of Agriculture and Food Systems (pp. 313-329). 10.1016/B978-0-444-52512-3.00171-6

Lim, M., Han, G.-C., Ahn, J.-W., \& You, K.-S. (2010). Environmental remediation and conversion of carbon dioxide $(\mathrm{CO}(2))$ into useful green products by accelerated carbonation technology. International Journal of Environmental Research and Public Health, 7(1), 203-228. 10.3390/ijerph7010203

Mancino, C. F., \& Pepper, I. L. (1992). Irrigation of Turfgrass with Secondary Sewage Effluent: Soil Quality. Agronomy Journal, 84(4), 650.

Marcum, K. B. (2006). Use of saline and nonpotable water in the turfgrass industry: Constraints and developments. Agricultural Water Management, 80(13), 132-146.

McCoy. (2006). Golf Course Soils and Water Science. USA: Ohio State Univ.

Miyamoto, S., Chacon, A., Hossain, M., \& Martinez, I. (2005). Soil Salinity of Urban Turf Areas Irrigated with Saline Water I. Spatial Variability. Landscape and Urban Planning, 71(2-4), 233-241. 
10.1016/j.landurbplan.2004.03.006

Mzezewa, J., Gotosa, J., \& Nyamwanza, B. (2003). Characterisation of A Sodic Soil Catena for Reclamation and Improvement Strategies. Geoderma, 113(1-2), 161-175. 10.1016/S00167061(02)00337-3

Ok, C.-H., Anderson, S. H., \& Ervin, E. H. (2003). Amendments and Construction Systems for Improving the Performance of SandBased Putting Greens. Agronomy Journal, 95(6), 1583-1590. 10.2134/agronj2003.1583

Qian, Y. L., Wilhelm, S. J., \& Marcum, K. B. (2001). Comparative Responses of Two Kentucky Bluegrass Cultivars to Salinity Stress. Crop Science, 41(6), 1895-1900. 10.2135/cropsci2001.1895

Rytwo, G., Banin, A., \& Nir, S. (1996). Exchange Reactions in the Ca-Mg-NaMontmorillonite System. Clays and Clay Minerals, 44(2), 276-285. 10.1346/CCMN.1996.0440212

Shainberg, I., Sumner, M. E., Miller, W. P., Farina, M. P. W., Pavan, M. A., \& Fey, M. V. (1989). Use of Gypsum on Soils: A Review. In B. . Stewart (Ed.), Advances in Soil Science. New York: Springer (pp. 1111). 10.1007/978-1-4612-3532-3_1

Silvertooth, J. C. (2001). Saline and Sodic Soil Identification and Management for Cotton. Retrieved June 29, 2019, from University of Arizona website: https://cals.arizona.edu/crop/cotton/soil $\mathrm{mgt} / \mathrm{saline}$ sodic_soil.html

Thiel, G., Lynch, J., \& Läuchli, A. (1988). Short- term Effects of Salinity Stress on the Turgor and Elongation of Growing Barley Leaves. Journal of Plant Physiology, 132(1), 38-44. 10.1016/S01761617(88)80180-9

Thompson, R. B., Gallardo, M., Fernández, M. D., Valdez, L. C., \& Martínez-Gaitán, C. (2007). Salinity Effects on Soil Moisture Measurement Made with a Capacitance Sensor. Soil Science Society of America Journal, 71, 1647-1657. 10.2136/sssaj2006.0309

Waltz, F. C., Quisenberry, V. L., \& McCarty, L. B. (2003). Physical and Hydraulic Properties of Rootzone Mixes Amended with Inorganics for Golf Putting Greens. Agronomy Journal, 95(2), 395-404.

Wasura, J. P., \& Petrovic, A. M. (2001). Physical stability of inorganic amendments used in turfgrass rootzones. Int. Turfgrass Soc. J. Research, 9, 637-641.

Wilhelm, S., Alshammary, S., \& Qian, Y. (2010). Establishment, Growth and Irrigation Requirements of Kentucky Bluegrass and Tall Fescue as Influenced by Two Irrigation Water Sources. Research Journal of Environmental Sciences, 4(5), 443-451. 10.3923/rjes.2010.443.451

Yoon, Y. B., \& Lee, J. S. (1992). The Growth and Thatch Accumulation of Kentucky Bluegrasses As Affected By Cutting Management 1. Varietal Differences Under Removing Clipping Residues. Korea Journal of Turfgrass Science, 6(1), 29-37. 